\title{
IMPLEMENTASI MODEL PEMBELAJARAN COOPERATIVE SCRIPT BERBANTUAN MIND MAPPING DENGAN MODEL PEMBELAJARAN DIRECT INSTRUCTION TERHADAP KEMAMPUAN KREATIVITAS MAHASISWA PADA MATA KULIAH MICROTEACHING
}

\author{
Junarti \\ Pendidikan Matematika, FPMIPA, IKIP PGRI Bojonegoro \\ e-mail: juniartibjn@gmail.com
}

\begin{abstract}
This research is meant to:1) see the difference influence of Cooperative Script Model with the help of mind mapping with Direct Instructional teaching model to students' creativity skill; 2) to prove the affectivity of Cooperative Script model implementation with the help of Mind Mapping in in improving Student's creativity in applying basic teaching skill in Micro Teaching simulation activity; 3) to prove the implementation of Direct Instruction model in improving students' creativity in applying basic teaching skill in micro teaching simulation. This research uses experimental method with two groups pre-test post-test. The result shows that: (1) the implementation of cooperative script model with the help of mind mapping is proven to be effective in improving student's creativity in applying basic teaching skills in simulation activity can be seen from the experiment group where 11 skills (indicator formulation skill, apperception skill, opening skill, questioning skill, using variation skill, class management skill, discussion guidance skill, individual teaching skill, material mastery skill, class mastery skill and media usage skill) are showing the average score of more than $80,(2)$ the implementation of direct instruction model can improve student's creativity in applying basic teaching skills where 6 basic skills (indicator formulation skill, giving apperception skill, lesson opening skill, questioning skill, class management skill and individual teaching skill) are able to achieve average scores of more than 80 , and (3) the misconception done by students can be categorized as basic mathematical misconception which is caused by apperception mistake and understanding.
\end{abstract}

Keywords: Teaching Model; Cooperative Script; Mind Mapping; Direct Instruction; Creativity

\begin{abstract}
Abstrak: Tujuan penelitian ini adalah untuk mengetahui: (1) perbedaan pengaruh model pembelajaran Cooperative Script berbantuan mind mapping dengan model pembelajaran Direct Instruction terhadap kemampuan kreativitas mahasiswa pada mata kuliah Microteaching; (2) implementasi model pembelajaran Cooperative Script berbantuan mind mapping terhadap peningkatan kreatifitas mahasiswa dalam mengaplikasikan Keterampilan Dasar Mengajar pada kegiatan simulasi mata kuliah Microteaching; (3) implementasi model pembelajaran Direct Instruction terhadap peningkatan kreatifitas mahasiswa dalam mengaplikasikan Keterampilan Dasar Mengajar pada kegiatan simulasi mata kuliah Microteaching. Metode penelitian yang digunakan adalah eksperimen dengan menggunakan desain two group pre-test pos-test. Hasil penelitian: (1) terdapat perbedaan pengaruh implementasi model pembelajaran Cooperative Script berbantuan mind mapping dengan model pembelajaran Direct Instruction terhadap kemampuan kreativitas mahasiswa pada mata kuliah Microteaching, (2) implementasi model pembelajaran Cooperative Script berbantuan mind mapping dapat meningkatkan kreatifitas mahasiswa dalam mengaplikasikan Keterampilan Dasar Mengajar pada kegiatan simulasi terdapat 11
\end{abstract}


kemampuan (kemampuan merumuskan indikator, memberikan apersepsi, membuka pelajaran, bertanya, menggunakan variasi, mengelola kelas, membimbing diskusi, mengajar perorangan, menguasai materi, menguasai kelas, menggunakan media) yang mendapat nilai rata-rata di atas 80, dan (3) implementasi model pembelajaran Direct Instruction dapat meningkatkan kreatifitas mahasiswa dalam mengaplikasikan Keterampilan Dasar Mengajar pada kegiatan simulasi yaitu terdapat 6 kemampuan (kemampuan merumuskan indikator, memberikan apersepsi, membuka pelajaran, bertanya, mengelola kelas, dan mengajar perorangan) yang mendapat nilai rata-rata di atas 80. Kesalahan Konsep yang dilakukan mahasiswa dapat dikategorikan kesalahan konsep matematika dasar yang dikarenakan kesalahan persepsi dan pemahaman.

Kata Kunci: Cooperative Script; Mind Mapping; Direct Instruction; Kreatifitas

\section{PENDAHULUAN}

Pembelajaran matematika di sekolah diharapkan menjadi sesuatu kegiatan yang menyenangkan bagi siswa, sehingga mahasiswa sebagai calon guru matematika harus mempunyai kemampuan mengajar yang dapat dihandalkan. Namun kenyataannya masih banyak kesulitan yang ditemui dalam mempelajari matematika bagi siswa di sekolah, sehingga guru matematika perlu dipersiapkan semaksimal mungkin untuk dapat memotivasi kesulitan siswa di sekolah. Mahasiswa program studi pendidikan matematika, sudah selayaknya mampu dan terampil dalam menyampaikan/menstransfer atau menjadi guru matematika di sekolah.

Fakta di lapangan menunjukkan hasil nilai UAS Microteaching tahun 2014 bahwa kemampuan mahasiswa dalam menguasai, memahami dan menerapkan keterampilan dasar mengajar masih rendah yakni nilai rata-rata hasil tes adalah 62 dan hasil praktik (simulasi) sebesar 54 dari skala 100. Sedangkan nilai rata-rata kemampuan matematika dari Jurusan IPA mengalami penurunan yakni dari 60,4 menjadi 59,17. (www.antaranews.com, Mendikbud, 15 Mei 2015, Indriani, 12-1-2016).

Berdasarkan informasi nilai UN matematika tersebut, merupakan gambaran bahwa guru dan calon guru harus bekerja keras untuk bisa mengentaskan atau minimal menaikkan nilai rata-rata UN matematika tersebut. Sudah selayaknya, harapan semua guru maupun calon guru matematika bahwa sebagai pendidik mempunyai tanggungjawab yang besar untuk mengentaskan para siswa di sekolah.

Salah satu usaha yang dapat dimanipulasi adalah menerapkan berbagai model dan metode dalam pembelajaran. Berbagai pelatihan/workshop, dan bahkan perubahan/perbaikan kurikulum sudah dilakukan oleh pemerintah.

Dalam hal ini pemerintah sudah cukup optimal untuk dapat meningkatkan hasil UN Matematika agar lebih baik lagi, dan bahkan sudah banyak anggaran yang dikeluarkan untuk meningkatkan kualitas guru. Namun tidak ada salahnya jika usaha yang lainnya dapat dilakukan, misalnya melalui pengoptimalan calon guru yang ada di Perguruan Tinggi Negeri maupun swasta melalui peningkatan kemampuan mahasiswa dalam memahami, menguasai, dan dalam keterampilan dasar mengajar serta keterampilan lanjutan.

Rendahnya kemampuan mengajar mahasiswa bisa menjadikan salah satu 
penyebab rendahnya nilai UN pada mata pelajaran UN, yakni dalam artian menurunnya kemampuan guru mengajar. Sudah selayaknya perguruan tinggi LPTK mampu menyiapkan calon guru yang handal sesuai dengan tuntutan pemerintah pada saat ini, yakni menyiapkan anak bangsa yang siap mengahadapi persaingan global.

Mata kuliah Microteaching, merupakan salah satu mata kuliah yang menuntut mahasiswa untuk terampil menerapkan keterampilan dasar mengajar. Kebutuhan di lapangan terutama guru matematika harus mampu menjadi calon guru yang dapat melakukan pemecahan segala kesulitan yang dimiliki siswa di sekolah dari berbagai karakteristik dan jenis kesulitan matematika.

Pada mata kuliah Microteaching, mahasiswa kurang dapat memahami dan kurang termotivasi dikarenakan materinya membosankan bagi mahasiswa. Hal itulah yang menyebabkan mahasiswa begitu malas, tidak suka bahkan enggan dalam belajar Microteaching (berdasarkan hasil observasi yang dilakukan oleh peneliti pada saat mengampu mata kuliah Microteaching tahun 2014).

Proses belajar mengajar dan pemikiran kreatif pada mata kuliah Microteaching, serta kesulitan yang dialami terdapat beberapa faktor yang mempengaruhinya. Menurut Syah (2007:144) bahwa faktor-faktor yang mempengaruhi hasil belajar mahasiswa dapat dibedakan menjadi tiga macam, yakni: 1) faktor internal, yakni keadaan atau kondisi jasmani dan rohani mahasiswa yang meliputi aspek fisiologis (yang bersifat jasmaniah) dan aspek psikologis (yang bersifat rohaniah), 2) faktor eksternal, yakni kondisi lingkungan di sekitar mahasiswa yang meliputi faktor lingkungan sosial dan faktor lingkungan non sosial, 3) faktor pendekatan belajar (approach to learning), yakni jenis upaya belajar mahasiswa yang meliputi strategi dan metode yang digunakan mahasiswa untuk melakukan kegiatan mempelajari materi-materi pelajaran yang meliputi pendekatan tinggi (speculative dan achieving), pendekatan menengah (analitical dan deep), dan pendekatan rendah (reproductive dan surface).

Suatu kegiatan yang tidak terpisahkan dari proses pembelajaran adalah kegiatan mengajar. Menurut Sardiman (dalam Nuha, 2013) mengajar adalah usaha untuk menciptakan kondisi yang kondusif agar berlangsung kegiatan belajar yang bermakna dan optimal, sehingga dapat mengoptimalisasikan kegiatan belajar dengan hasil yang bermakna. Sehingga dalam implementasinya dosen harus selalu berupaya untuk mencari dan menemukan berbagai strategi pembelajaran yang dapat memperkaya pengalaman belajar anak melalui serangkaian kegiatan yang dapat mengeksplorasi lingkungan melalui interaksi aktif terhadap lingkungan fisik maupun sosialnya.

Akan tetapi hal itu tidaklah mudah karena komposisi mahasiswa dalam kelas umumnya terdiri dari mahasiswa yang memiliki tingkat kecerdasan yang bervariasi baik dalam hal kecerdasan intelektual, verbal, visual maupun interpersonal.

Kondisi ini menyebabkan mahasiswa yang tingkat kecerdasan intelektualnya kurang cenderung bersifat pasif (kurang interaktif), bersikap acuh (kurang partisipatif), dan merasa rendah diri karena tidak mampu berperan. Pada akhirnya mereka malas dan melakukan 
hal-hal yang tidak ada kaitannya dengan pelajaran. Pembelajaran merupakan suatu proses kerjasama, tidak hanya menitikberatkan pada kegiatan dosen atau kegiatan mahasiswa saja, akan tetapi dosen dan mahasiswa secara bersamasama berusaha mencapai tujuan pembelajaran yang telah ditentukan. Mahasiswa adalah subyek utama dalam belajar. Mahasiswa harus mempunyai motivasi, kritis dan kreatif dalam perkuliahan, sehingga pembelajaran berlangsung secara efektif.

IKIP PGRI Bojonegoro Program

Studi Pendidikan Matematika adalah salah satu Perguruan Tinggi yang mahasiswanya cenderung tidak antusias terhadap perkuliahan apapun, karena menurut mahasiswa perkuliahan sangat membosankan sehingga menjadi sulit untuk dipahami. Hal itu terbukti dari observasi pada mata kuliah Microteaching tahun 2014 yang menyatakan bahwa motivasi belajar mahasiswa rendah dan kurang bersemangat serta kurang kreativitas.

Proses pembelajaran yang hanya terfokus pada dosen, mahasiswa hanya mendengarkan dan mencatat apa yang ditulis oleh dosen di papan tulis, sehingga dosen mendominasi seluruh kegiatan pembelajaran mengakibatkan mahasiswa menjadi pasif dan kurang kreatif. Kegiatan seperti inilah yang memicu mahasiswa ke dalam kejenuhan proses belajar mengajar. Mahasiswa akan merasa bosan sehingga mengakibatkan mahasiswa cenderung melakukan hal-hal lain yang tidak berkenaan dengan belajar, seperti bercanda dengan teman, bahkan ada yang sampai tertidur.

Metode pengajaran yang bervariasi merupakan salah satu upaya agar mahasiswa selalu menunjukkan ketekunan, perhatian, keantusiasan, motivasi yang tinggi dan kesediaan berperan serta secara aktif. Pada dasarnya mahasiswa satu berbeda dengan mahasiswa yang lainnya. Karena perbedaan ini diperlukan sebuah alternatif pembelajaran yang memungkinkan terpenuhinya kemampuan individual mahasiswa. Salah satu alternatifnya adalah menerapkan model pembelajaran cooperative script dengan berbantuan peta pikiran.

Model Cooperative Script dipilih karena bisa mengajak mahasiswa lebih berfikir kreatif serta memiliki daya ingat lebih baik (Shoimin, 2014). Mahasiswa juga diberi kesempatan untuk lebih aktif, saling bekerjasama dan lebih berani mengemukakan pendapatnya. Hal ini disebabkan karena dalam model pembelajaran Cooperative Script mahasiswa belajar secara berpasang-pasangan dan berani untuk mempresentasikan jawabannya. Demikian pula berdasarkan hasil penelitian yang dilakukan oleh Muniroh (2010) menyatakan bahwa model pembelajaran Cooperative Script dapat meningkatkan daya ingat dan kreativitas siswa dari $63,33 \%$ menjadi $75 \%$. Daya ingat mahasiswa sangat diperlukan untuk memunculkan kreativitas dalam pemecahan masalah, karena kreativitas merupakan kemampuan untuk membuat kombinasi baru berdasarkan data atau informasi yang telah dikenal sebelumnya.

Menurut Sani (2013) mind mapping merupakan salah satu bentuk pembelajaran yang digunakan untuk melatih kemampuan penyajian isi (content) materi dengan pemetaan pikiran. Peta pikiran dapat membantu mahasiswa berpikir secara kreatif sekaligus kritis, mengingat dengan baik pelajaran, memahami isi bacaan, dan penugasan lain 
yang diberikan serta membantu mahasiswa mempersiapkan presentasi dengan cara mengembangkan ide-ide pemikirannya.

Bertolak dari berbagai kondisi yang diuraikan di atas, muncul pemikiran untuk mengimplementasikan model pembelajaran Cooperative Script berbantuan Mind Mapping dengan model pembelajaran Direct Instruction terhadap kemampuan kreatifitas mahasiswa pada mata kuliah Microteaching.

\section{METODE}

Metode penelitian yang digunakan adalah eksperimen dengan menggunakan desain two group pre-test pos-test, yaitu suatu desain penelitian yang digunakan untuk meneliti ada atau tidak perbedaan rerata pada dua populasi dari perlakuan model pembelajaran yang berbeda terhadap kemampuan kreatifitas mahasiswa dalam mengaplikasikan keterampilan dasar mengajar.

Metode yang selanjutnya digunakan pengamatan secara kualitatif untuk menganalisis kesalahan konsep matematika sekolah yang disampaikan ketika menjelaskan malam simulasi pada mata kuliah Microteaching. Penelitian ini dilakukan pada mahasiswa yang mengikuti mata kuliah Microteaching pada semester Genap 2015/2016 Program Studi Pendidikan Matematika Fakultas Pendidikan Matematika dan IPA IKIP PGRI Bojonegoro.

Subjek penelitian terdiri dari mahasiswa yang memiliki kemampuan penguasaan kelompok atas, sedang dan rendah. Kriteria mahasiswa yang digunakan sebagai subjek didasarkan pada skor tertinggi pada masing-masing kelompok mahasiswa. Masing-masing subjek selanjutnya diamati kemampuan komunikasi, kemampuan pemecahan masalah, kemampuan membuat ilustrasi, dan kemampuan menjelaskan secara lisan dalam mengajar.

Instrumen yang digunakan terdiri dari instrumen pengukuran kemampuan penguasaan matematika, instrumen pengukuran kemampuan pemecahan masalah, instrumen pengukuran kemampuan mengkomunikasikan, dan instrumen pengukuran kemampuan membuat ilustrasi konsep matematika sekolah. Bentuk instrumen yang digunakan untuk pengukuran kemampuan penguasaan matematika adalah objektif tentang matematika SMA kelas 1, kelas 2, dan kelas 3 sebanyak 60 butir soal. Bentuk instrumen untuk mengukur pemecahan masalah adalah uraian sebanyak 10 soal dengan bentuk soal cerita. Bentuk instrumen untuk pengukuran kemampuan megkomunikasikan dan kemampuan membuat ilustrasi adalah dengan panduan pengamatan yang diadopsi dari panduan penilaian Praktek Pengalaman Lapangan (PPL).

Analisis data dilakukan secara kualitatif. Nilai kemampuan penguasaan matematika dikelompokkan menjadi tiga kelompok berdasarkan standar deviasi Arikunto (2009: 263), untuk menentukan kelompok tinggi, sedang, dan rendah. Dari masingmasing kelompok diambil subjek berdasarkan skor tertinggi dari masingmasing kelompok. Subjek yang sudah ditetapkan diberikan soal pemecahan masalah kemudian diamati kemampuan pemecahan masalah, dan dianalisis kualitatif. Selanjutnya dilakukan latihan mengajar dalam kegiatan simulasi untuk diamati kemampuan mengkomunikasikan dan diamati kemampuan membuat ilustrasi konsep matematika sekolah untuk 
mengkaji kemampuan kreatifitas mahasiswa.

\section{HASIL DAN PEMBAHASAN}

Uji prasyarat yang digunakan dalam penelitian ini adalah uji normalitas dengan Lilliefors dan uji homogenitas dengan metode Bartlett, serta uji keseimbangan serta uji hipotesis untuk menganalisis data penelitian dengan statistik.

Langkah-langkah uji statistik sebagai berikut:

a. Uji Normalitas

Uji normalitas dilakukan dengan uji Liliefors. Hasil perhitungan uji normalitas kelompok kontrol diperoleh $\mathrm{L}_{\mathrm{obs}}=0.89, \mathrm{~L}_{\text {tabel }}=0.14$ $\left(H_{0}\right.$ diterima) sedangkan hasil perhitungan uji normalitas kelompok eksperimen diperoleh $\mathrm{L}_{\mathrm{obs}}=1.00$, $\mathrm{L}_{\text {tabel }}=0.13 \quad\left(H_{0}\right.$ diterima $) . \quad$ Kedua kelompok berasal dari populasi yang normal.

b. Uji Homogenitas

Uji homogenitas dilakukan menggunakan uji Bartlett. Hasil pengujian homogenitas dilakukan pada kelompok kontrol berdasarkan hasil nilai Ujian Tengah Semester. Uji homogenitas kelompok kontrol menunjukkan bahwa $\mathrm{F}_{\mathrm{obs}}=0.736$ dan $\mathrm{F}_{\mathrm{tab}}=1.658$ sehingga memberikan kesimpulan $H_{0}$ diterima dan data homogen. Hasil pengujian untuk kelompok eksperimen menunjukkan bahwa $\mathrm{F}_{\text {obs }}=0.749$ dan $\mathrm{F}_{\mathrm{tab}}=1.658$ sehingga memberikan kesimpulan $H_{0}$ diterima. Hasil pengujian homogenitas dari kelompok control dan eksperimen menunjukkan bahwa kedua kelompok homogen. c. Uji Keseimbangan

Uji keseimbangan menggunakan uji anava satu jalan dengan sel tak sama. Diperoleh hasil uji keseimbangan dengan anava satu jalan sel tak sama. Hasil uji keseimbangan antara kelompok eksperimen dengan kelompok kontrol menunjukkan bahwa $\mathrm{t}_{\mathrm{obs}}=-0.028$ dan $\mathrm{t}_{\text {table }}=1.987$ sehingga kelompok kontrol dan eksperimen seimbang.

d. Uji Hipotesis Penelitian

Uji hipotesis dilakukan untuk mengetahui ada tidaknya pengaruh penerapan model pembelajaran Cooperative Script berbantuan mind mapping dengan model pembelajaran Direct Instruction terhadap kemampuan kreativitas mahasiswa pada mata kuliah Microteaching. Uji hipotesis menggunakan uji t. Adapun hasil uji $\mathrm{t}$ disajikan pada Tabel 1 . berikut.

Tabel 1. Hasil Uji Hipotesis

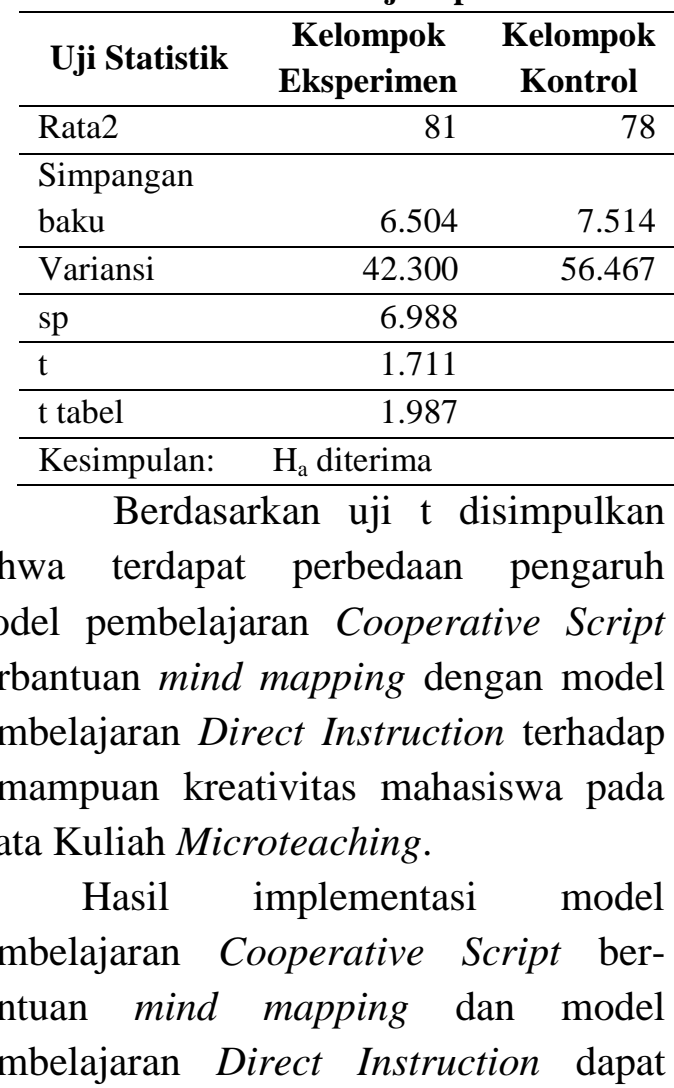


meningkatkan kreatifitas mahasiswa sar mengajar pada kegiatan simulasi pada dalam mengaplikasikan keterampilan damata kuliah Microteaching berikut.

Tabel 2. Kemampuan Kreatifitas Komponen Keterampilan Mengajar Kelompok Eksperimen dan

Kontrol

\begin{tabular}{clccc}
\hline $\begin{array}{c}\text { No } \\
\text { Urut }\end{array}$ & \multicolumn{1}{c}{ Interval Nilai } & $\begin{array}{c}\text { Kelompok } \\
\text { Kontrol }\end{array}$ & $\begin{array}{c}\text { Kelompok } \\
\text { Eksperimen }\end{array}$ & $\%$ \\
\hline 1 & Kemampuan merumuskan indikator & 92 & 95 & 3,16 \\
\hline 2 & Kemampuan menentukan materi apersepsi & 94 & 98 & 4,08 \\
\hline 3 & Kemampuan membuka & 85 & 89 & 4,49 \\
\hline 4 & Kemampuan bertanya & 80 & 88 & 9,09 \\
\hline 5 & Kemampuan memberikan penguatan & 78 & 78 & 0.00 \\
\hline 6 & Kemampuan menggunakan variasi & 67 & 83 & 7,23 \\
\hline 7 & Kemampuan menjelaskan & 66 & 79 & 3,80 \\
\hline 8 & Kemampuan mengelola kelas & 86 & 86 & 0,00 \\
\hline 9 & Kemampuan membimbing diskusi & 68 & 80 & 15,00 \\
\hline 10 & Kemampuan mengajar perorangan & 88 & 88 & 0,00 \\
\hline 11 & Kemampuan menguasai materi & 65 & 87 & 9,52 \\
\hline 12 & Kemampuan menguasai kelas & 75 & 79 & 13,79 \\
\hline 13 & Kemampuan menutup pelajaran & 68 & 88 & 0,06 \\
\hline 14 & Kemampuan menggunakan media & 53 & 78 & 32,05 \\
\hline 15 & Kemampuan menyusun soal sesuai indikator & & & \\
\hline
\end{tabular}

Berdasarkan data pada Tabel 2. terdapat 11 kemampuan yang mendapat nilai rata-rata di atas 80 oleh kelompok eksperimen, yakni kemampuan merumuskan indikator, memberikan apersepsi, membuka pelajaran, bertanya, menggunakan variasi, mengelola kelas, membimbing diskusi, mengajar perorangan, menguasai materi, menguasai kelas, menggunakan media. Hal ini menunjukkan secara rata-rata mahasiswa mempunyai kemampuan baik.

Sedangkan kelompok kontrol terdapat 6 kemampuan dengan nilai ratarata di atas 80, yakni kemampuan merumuskan indikator, memberikan apersepsi, membuka pelajaran, bertanya, mengelola kelas, mengajar perorangan. Hal ini menunjukkan bahwa mahasiswa mempunyai kemampuan baik.

Penerapan model pembelajaran Cooperative Script berbantuan mind mapping memberikan pengaruh yang berbeda dengan penerapan model pembelajaran Direct Instruction terhadap kreatifitas keterampilan dasar mengajar.
Perbedaan tersebut terletak pada kemampuan membimbing diskusi, kemampuan mengelola kelas, dan kemampuan menyusun soal sesuai indikator.

Sepuluh kemampuan kreatifitas yang lain yang dapat diamati diantaranya adalah kemampuan dalam: (1) memilih dan mengungkapkan materi apersepsi, (2) analisis materi, (3) memberikan ilustrasi verbal lisan dan secara tertulis, (4) penguasaan materi, (5) komunikasi matematika secara lisan dan tulisan, (6) menjelaskan yang berkaitan dengan pemahaman siswa ditinjau dari aspek kognitif siswa yakni ingatan, pemahaman, keterampilan, (7) memotivasi siswa, (8) melakukan variasi mengajar, dan (9) menggunakan alat bantu mengajar

e. Analisis Kualitatif

1) Hasil Pengamatan Kelompok Eksperimen dengan Model Pembelajaran Cooperative Script berbantuan Mind Mapping

Hasil Pengamatan Kegiatan Simulasi 
a) Mahasiswa 1:

Hasil pengamatan: (1) rumusan indikator pada RPP cukup operasional, tapi beberapa tidak sesuai dengan yang disampaikan, (2) rumusan indikator sudah nampak terukur dengan baik, dan (3) kegiatan Belajar Mengajar (langkah-langkah mengajar) tidak dirumuskan dengan bahasa yang komunikatif, tetapi sudah menggambarkan adanya interaksi multi arah. Metode atau model mengajar yang akan digunakan tidak dituliskan secara jelas, (4) penilaian Tampilan: pada pembukaan (pendahuluan): apersepsi diberi-kan dengan baik. Kegiatan Inti: tidak adanya variasi pola interaksi, tidak adanya teknik penunjukan, masih sering dilakukan kalimat yang memancing suara koor (suara bersama) tanpa ada pengelolaan dan pengarahan kegiatan siswa, tidak adanya penguatan yang diberikan siswa padahal siswa sudah merespon pertanyaan guru. Keterampilan menjelaskan masih nampak kurang persiapan atau kurang menguasai. Pertanyaan yang dilontarkan untuk mengukur kemampuan siswa, masih sering menggunakan "apakah sudah paham?" Penutup: kesimpulan tidak ditulis, tes formatif, dan penekanan serta tindak lanjut dilakukan dengan baik, dan (5) judul tidak ditulis, Perintah untuk contoh tidak ditulis di papan. Batasan jawaban contoh soal tidak diberikan pembatasan yang baik

b) Mahasiswa 2:

Hasil pengamatan: (1) tidak ada penguatan, (2) tidak ada alat bantu yang digunakan, (3) tidak ada perintah soal di contoh soal, (4) contoh dan soal latihan yang diberikan tidak sesuai dengan konsep awal yang diberikan.

c) Mahasiswa 3:

Hasil pengamatan menunjukkan: (1) Sering terdengar penjelasan guru yang direspon dengan jawaban seperti "suara koor", (2) tidak ada perintah soal di contoh soal dan (3) tulisan di papan terlalu kecil

d) Mahasiswa 4:

Hasil pengamatan: (1) ada penguatan tapi pemberiannya sambil membelakangi siswa, (2) pengukuran indicator masih menggunakan kata tanya seperti "sudah paham?". (3) rumusan indikator kurang operasional

e) Mahasiswa 5:

Hasil pengamatan: (1) soal yang digunakan untuk mengukur indikator di akhir pelajaran tidak sesuai dengan rumusan pada indicator, (2) guru masih bicara dengan papan tulis, (3) pengukuran indikator masih menggunakan kata tanya seperti "sudah paham?"

2) Hasil Pengamatan Kelompok Kontrol dengan Model Direct Instruction

Pengamatan pada kelompok kontrol dengan penerapan model pembelajaran Direct Instruction diperoleh hasil pengamatan sebagai berikut. 
a) Mahasiswa 1

Hasil pengamatan: (1) sering menyebutkan kata-kata "ya" diakhir kalimat, (2) cara menyebutkan atau menginfokan indikator masih seperti membaca,

(3) menggunakan penguatan tapi masih sering menggunakan dengan menyuruh tepuk tangan setiap respon yang diberikan siswa, (4) teknik pelontaran pertanyaan tidak diorganisasi dengan baik, (5) masih terdengar respon siswa dengan suara siswa koor (suara bersama), dan (6) teknik penunjukkan kurang terorganisir dengan baik penulisan yang kurang tepat

b) Mahasiswa 2

Hasil pengamatan menunjukkan: (1) tidak ada alat bantu mengajar, (2) tidak menulis judul materi, (3) banyak menggunakan kata "ya" diakhir kalimat yang disampaikan, (4) masih ada jawaban/respon dengan suara bersama (suara koor), (5) tidak menulis perintah pada contoh soal, (6) ada penguatan tetapi terlalu pelan, (7) menggunakan kata "bisa dipahami ya?"

c) Mahasiswa 3

Hasil pengamatan: (1) judul tidak ditulis, (2) memberikan penguatan tapi dengan kata" terimakasih" sebaiknya diganti dengan "ok" atau "ya bagus" atau "anggukan", (3) tidak ada klarifikasi jawaban siswa di papan dengan jawaban siswa yang lain, dan (4) masih terdapat penulisan yang salah.

d) Mahasiswa 4

Hasil pengamatan menunjukkan: (1) komunikasinya kurang lugas,
(2) kurang persiapan alat bantu yang lain jika alat yang disiapkan tidak dapat digunakan, (3) ada keadaan yang tidak dapat diduga muncul pada saat mengajar

e) Mahasiswa 5

Hasil pengamatan: (1) suara guru terlalu datar, kurang intonasi, (2) terlalu fokus dengan materinya sendiri, yakni sibuk dengan materi yang harus dituangkan di papan tulis, (3) tidak mengunakan penggaris pada saat menggambar bangun segitiga, jajargenjang dan besar sudut yang terbentuk pada gambar.

f) Mahasiswa 6

Hasil pengamatan: (1) metode tanya jawab tidak terlakukan, (2) masih ada suara koor, penguatan belum maksimal, (4) kesimpulan belum mengarahkan siswa untuk menyusun kesimpulan atau rangkuman, dan (5) rumusan indikator kurang operasional

Guru memiliki peran yang sangat penting dalam kegiatan belajar-mengajar, yaitu mengatur dan mengemudikan bahtera kehidupan kelas (Arikunto, 2015:327). Agar dapat melaksanakan peran tersebut seorang guru harus memiliki penguasaan yang baik terhadap keterampilan dasar mengajar.

Keterampilan dasar mengajar yang wajib dimiliki oleh seorang guru terdiri dari delapan hal, yang meliputi keterampilan dalam: (1) membuka dan menutup pelajaran, (2) bertanya dasar dan lanjutan, (3) memberikan penguatan, (4) mengadakan variasi (variasi media, variasi posisi, variasi pola interaksi), (5) mengelola kelas, (6) menjelaskan, dan (7) mengajar kelas kecil atau kelas besar baik 
perorangan maupun klasikal, dan (8) keterampilan lainnya yang tidak tertulis.

Guru matematika dituntut bukan hanya memiliki keterampilan dasar mengajar saja akan tetapi juga penguasaan konsep matematika. Untuk menunjang kemampuan dalam menjelaskan, mengelola kelas dan keterampilan lainnya diperlukan penguasaan konsep dan kemampuan mengkomunikasikan konsep matematika. Oleh sebab itu, mahasiswa sebagai calon guru harus mempunyai kemampuan penguasaan konsep matematika di sekolah maupun kemampuan cara menjelaskan atau kemampuan mengkomunikasikan konsep matematika dengan baik.

Tugas guru menurut Silver dan Smith (1996: 20) antara lain: 1) melibatkan siswa dalam setiap tugas matematika; 2) mengatur aktivitas intelektual siswa dalam kelas seperti diskusi dan komunikasi; 3) membantu siswa memahami ide matematika dan memonitor pemahaman siswa.

Untuk mengemban tugas tersebut di atas, guru harus mempunyai kemampuan yang sebanding dengan kebutuhan siswa. Kemampuan guru yang mumpuni yakni kemampuan dalam mengkomunikasikan konsep matematika baik secara verbal, lisan, tulisan serta dalam bentuk simbol dan ilustrasi.

Guru harus memiliki kemampuan gagasan secara praktis, sistematis, efektif, efisien dan sesuai sasaran serta terukur. Agar gagasan atau konsep yang disampaikan dapat mencapai pemahaman siswa, maka guru harus mampu mengkomunikasikannya secara baik, lengkap dan jelas.

Konsep dasar matematika merupakan kemampuan yang harus dikuasai secara utuh dan menyeluruh antara lain pemahaman dan keterampilan dalam penggunaan operasi dasar, kemampuan memahami makna simbol yang digunakan serta kemampuan penggunaan simbolik dengan tepat, sampai dengan kemampuan mengkomunikasikan pemahamannya melalui ilustrasi ataupun melalui bahasa verbal secara lisan dan tulisan.

Calon guru juga harus memiliki kemampuan yang berkaitan dengan kecakapan matematis, yang pertama adalah pemahaman konseptual (conceptual understanding) yaitu kemampuan yang berkaitan dengan pemahaman atau penguasaan terhadap konsep-konsep, operasi, dan relasi matematis. Mahasiswa harus bisa menyatakan ulang konsep yang telah dipelajari, mengklarifikasikan objekobjek berdasarkan dipenuhi tidaknya persyaratan membentuk konsep tersebut, memberikan contoh atau non-contoh dari konsep yang dipelajari, menyajikan konsep dalam berbagai macam bentuk representasi matematis, mengaitkan berbagai konsep, dan mengembangkan syarat perlu dan atau syarat cukup suatu konsep.

Kemampuan kecakapan matematis kedua adalah kelancaran prosedural yang mengacu pada pengetahuan tentang prosedur, pengetahuan tentang kapan dan bagaimana menggunakannya secara tepat, dan keterampilan melakukan prosedur secara fleksibel, akurat dan efisien. Diharapkan mahasiswa dapat dan mampu dalam hal: menggunakan prosedur, memanfaatkan prosedur, memilih prosedur, memperkirakan hasil suatu prosedur, memodifikasi atau memperhalus prosedur, dan mengembangkan prosedur. 
Ketiga, mahasiswa calon guru harus memiliki kompetensi strategis (strategic competence) yakni kemampuan untuk merumuskan, menyajikan, dan menyelesaikan masalah matematika. Kemampuan ini dapat diukur dari kemampuan dalam: memahami masalah, menyajikan suatu masalah secara matematik dalam berbagai bentuk (numerik, simbolik, verbal, atau grafis), memilih rumus, pendekatan atau metode yang tepat untuk memecahkan masalah; dan memeriksa kebenaran penyelesaian masalah yang telah diperoleh. Kemampuan pemecahan masalah matematika berdasar pada fleksibilitas. Fleksibilitas seseorang dapat berkembang melalui perluasan pengetahuan yang diperlukan untuk memecahkan masalahmasalah yang tidak rutin.

Keempat, kemampuan yang merujuk pada kemampuan berpikir logis, yaitu penalaran adaptif (adaptive reasoning). Selain kemampuan berpikir logis, mahasiswa harus pula mempunyai kemampuan untuk berpikir reflektif, kemudian kemampuan untuk menjelaskan, dan kemampuan untuk memberikan pembenaran. Kemampuan tersebut dapat diukur dengan tolok ukur yakni: menyusun dugaan, memberikan alasan atau bukti terhadap kebenaran suatu pernyataan, menarik kesimpulan dari suatu pernyataan, memeriksa kesahihan suatu argument, dan menemukan pola pada suatu gejala matematis.

Kelima, calon guru harus mempunyai kemampuan disposisi produktif (productive disposition) yakni kemampuan yang mengarah pada kecenderungan untuk mempunyai kebiasaan yang produktif, untuk melihat matematika sebagai hal yang masuk akal, berguna, bermakna, dan berharga, serta memiliki kepercayaan diri dan ketekunan dalam belajar atau bekerja dengan matematika. Kemampuan ini dapat ditunjukkan dengan perilaku: bersemangat, tidak mudah menyerah, percaya diri, memiliki rasa ingin tahu yang tinggi, dan mau berbagi.

Selain kecakapan matematis, mahasiswa calon guru juga harus memiliki kemampuan komunikasi matematika. Kemampuan komunikasi mahasiswa merupakan fondasi dalam membangun pengetahuan siswa terhadap matematika baik lisan maupun tulisan. Lima aspek komunikasi yang harus dimiliki oleh mahasiswa (Baroody, 1993), yakni sebagai berikut.

1. Representasi (representing), membuat representasi berarti membuat bentuk yang lain dari ide atau permasalahan.

2. Mendengar (listening), kemampuan dalam mendengarkan topik-topik yang sedang didiskusikan akan berpengaruh pada kemampuan siswa dalam memberikan pendapat akan komentar.

3. Membaca (reading), proses membaca merupakan kegiatan yang kompleks, karena di dalamnya terkait aspek mengingat, memahami, membandingkan, menganalisis, serta mengorganisasikan apa yang terkandung dalam bacaan.

4. Diskusi (discussing), dalam diskusi siswa dapat mengungkapkan dan merefleksikan pikiran-pikirannya berkaitan dengan materi yang sedang dipelajari.

5. Menulis (writing), menulis merupakan kegiatan yang dilakukan dengan sadar untuk mengungkapkan dan merefleksikan pikiran, yang dituangkan dalam media, baik kertas, computer maupun media lainnya. 
Menurut NCTM (Van de Walle, 2008:4) standar utama dalam pembelajaran matematika yaitu kemampuan pemecahan masalah (problem solving), kemampuan komunikasi (communication), kemampuan koneksi (connection), kemampuan penalaran (reasoning), dan kemampuan representasi (representation). Kelima standar tersebut mempunyai peranan penting dalam kurikulum matematika.

Dalam pembelajaran diperlukan berkomunikasi, untuk berkomunikasi diperlukan alat berupa bahasa. Matematika merupakan alat atau bahasa yang digunakan untuk berkomunikasi. Matematika merupakan bahasa yang universal terbuti dari satu simbol dalam matematika dapat dipahami oleh setiap orang di dunia ini, misalnya dalam matematika menyatakan jumlah menggunakan lambang $\sum$ (dibaca sigma). (Zaenab, 2013: 3)

Menurut Barton $(2008,152)$, ideide matematika yang akan dikomunikasikan harus sistematis, sehingga matematika dihasilkan. Hal ini yang menyebabkan matematika dan bahasa harus berkembang bersama.

Menurut Artmanda W. (Kamus bahasa Indonesia online secara terminologi) komunikasi berarti pengiriman dan penerimaan atau berita antara dua orang atau lebih sehingga pesan yang dimaksud dapat dipahami; hubungan; kontak. Komunikasi adalah cara untuk berbagi (sharing) ide, gagasan dan mengklarifikasi pemahaman kepada sesama. Dari beberapa pengertian ini dapat disimpulkan bahwa komunikasi adalah proses penyampaian suatu informasi dari satu orang ke orang lain sehingga mereka mempunyai makna yang sama terhadap informasi tersebut.
The Intended Learning Outcomes (ILOs) menerangkan bahwa komunikasi matematika adalah suatu keterampilan penting dalam matematika yaitu kemampuan mengekspresikan ide-ide matematika secara koheren kepada teman, guru dan lainnya melalui bahasa lisan dan tulisan (dikutip Armiati, 2009).

Komunikasi matematika menurut NCTM adalah kemampuan siswa dalam menjelaskan suatu algoritma dan cara unik untuk pemecahan masalah, kemampuan siswa mengkonstruksikan dan menjelaskan sajian fenomena dunia nyata secara grafis, kata-kata/kalimat, persamaan, tabel dan sajian secara fisik atau kemampuan siswa memberikan dugaan tentang gambar-gambar geometri (dikutip Jazuli, 2009).

Melalui komunikasi, ide matematika dapat dieksploitasi dalam berbagai perspektif; cara berfikir siswa dapat dipertajam; pertumbuhan pemahaman dapat diukur; pemikiran siswa dapat dikonsolidasikan dan diorganisir; pengetahuan matematika dan pengembangan masalah siswa dapat ditingkatkan; dan komunikasi matematika dapat dibentuk. Sesuai dengan tingkatan pendidikan maka tingkat kemampuan komunikasi matematika menjadi beragam. Komunikasi matematis sangat penting karena matematika tidak hanya menjadi alat berfikir yang membantu siswa untuk mengembangkan pola, menyelesaikan masalah dan menarik kesimpulan tetapi juga sebagai alat untuk mengkomunikasikan pikiran, ide dan gagasan secara jelas, tepat dan singkat.

Kemampuan mahasiswa dalam membuat ilustrasi konsep matematika SMA dalam mengajar masih belum optimal, mahasiswa masih cenderung sama dengan konsep yang terdapat pada 
buku sumber atau buku pegangan guru. Guru kurang berani membuat sendiri ilustrasi, kurang pengalaman dalam memberi ilustrasi sesuai dengan perkembangan kemampuan siswa dan sesuai dengan makna konsep yang dijelaskan.

Kemampuan guru atau calon guru dalam menjelaskan sangatlah dibutuhkan dalam pemahaman konsep oleh siswa secara mudah. Melalui ilustrasi siswa dapat memahami konsep matematika secara sederhana dan mudah untuk dicermati dan dipahami. Dengan ilustrasi maka penjelasan materi tidak banyak menggunakan konsep yang abstrak. Konsep matematika dianggap sulit dipahami oleh siswa, karena banyaknya simbol-simbol yang sulit dipahami oleh siswa, atau guru belum mampu menjelaskan simbol tersebut secara mudah sesuai dengan bahasa siswa.

\section{SIMPULAN}

Berdasarkan analisis data, maka hasil dari penelitian ini dapat disimpulkan sebagai berikut.

1. Terdapat perbedaan pengaruh model pembelajaran Cooperative Script berbantuan mind mapping dengan model pembelajaran Direct Instruction terhadap kemampuan kreativitas mahasiswa pada mata kuliah Microteaching.

2. Implementasi model pembelajaran Cooperative Script berbantuan mind mapping dapat meningkatkan kreatifitas mahasiswa dalam mengaplikasikan Keterampilan Dasar Mengajar (terdapat 11 keterampilan) pada kegiatan simulasi, yakni keterampilan dalam: (1) merumuskan indikator, (2) memberikan apersepsi, (3) membuka pelajaran, (4) bertanya,
(5) menggunakan variasi, mengelola kelas, (7) membimbing diskusi, (8) mengajar perorangan, (9) penguasaan materi, (10) penguasaan kelas, dan (11) menggunakan media.

3. Implementasi model pembelajaran Direct Instruction dapat meningkatkan kreatifitas mahasiswa dalam mengaplikasikan Keterampilan Dasar Mengajar (terdapat 6 kemampuan), yakni kemampuan dalam (1) merumuskan indikator, (2) memberikan apersepsi, (3) membuka pelajaran, (4) bertanya, (5) mengelola kelas, (6) mengajar perorangan.

2. Sepuluh kemampuan lain yang dapat diamati adalah kemampuan dalam: (1) memilih dan mengungkapkan materi apersepsi, (2) analisis materi, (3) memberikan ilustrasi verbal lisan dan secara tertulis, (4) penguasaan materi, (5) komunikasi matematika secara lisan, (6) komunikasi matematika secara tulisan, (7) menjelaskan yang berkaitan dengan pemahaman siswa ditinjau dari aspek kognitif siswa yakni ingatan, pemahaman, keterampilan, (8) memotivasi siswa, (9) melakukan variasi mengajar, dan (10) menggunakan alat bantu mengajar.

Berdasarkan kesimpulan penelitian ini dapat disampaikan saran sebagai berikut:

1. Kemampuan pedagogi mahasiswa dalam proses pembelajaran masih perlu ditingkatkan melalui latihan dalam simulasi mengajar dengan penerapan berbagai model, metode, strategi dan pendekatan pembelajaran. Selain itu, mahasiswa memerlukan arahan dan pembinaan yang intens 
dalam simulasi di dalam perkuliahan Microteaching.

2. Kemampuan dalam menguasai materi matematika yang akan disampaikan masih perlu ditingkatkan dan perlu dikuasai secara baik karena dapat mempengaruhi keterampilan pedagogi yaitu keterampilan dalam menjelaskan.

3. Berdasarkan kekurangan hasil penelitian ini, diharapkan untuk dilakukan penelitian lanjutan untuk dapat menggali dan mencari pola perkuliahan yang baik dan tepat dalam melatih dan membekali mahasiswa dalam meningkatkan kemampuan pedagogi-nya secara optimal.

\section{DAFTAR PUSTAKA}

Arikunto, S. (2012). Dasar-Dasar Evaluasi Pendidikan. Jakarta: Bumi Aksara.

Muniroh, K. (2010). Implementasi Pembelajaran dengan Model Cooperative Script sebagai Usaha untuk Meningkatkan Kreativitas dalam Pemecahan Masalah Matematika Siswa Kelas VIII MTs Wahid Hasyim Sleman
Yogyakarta,(Online),

http://eprints.uny.ac.id/1938/1/Penel itian_Khayyizatul_Muniroh.pdf), diakses 24 Januari 2015.

Nuha, Uli. (2013). Efektivitas Pembelajaran Matematika

Menggunakan Model Cooperative Script dengan Pendekatan Problem Posing terhadap Motivasi dan Hasil Belajar Matematika Siswa Kelas X di SMA Ma'arif Nu 1 Kemranjen. Penelitian tidak diterbitkan. Yogyakarta: UIN Sunan kalijaga.

Sani, R. A. (2013). Inovasi Pembelajaran . Jakarta: Bumi aksara.

Sardiman. (1994). Interaksi dan Motivasi Mengajar. Jakarta: Raja Grafindo.

Shoimin, A. (2014). 68 Model Pembelajaran Inovasi dalam Kurikulum 2013. Yogyakarta: ArRuzz Media.

Sugiyono. (2007). Statistika untuk Penelitian. Bandung: Alfabeta.

Syah, Muhibbin. (2007). Psikologi Belajar. Jakarta: PT Raja Grafindo Persada.

Trianto. (2009). Mendesain Model Pembelajaran Inovatif-Progresif. Jakarta:

Kencana. 